\title{
Bir Yeniden Yazım Örneği Olarak On Dokuzuncu Asır Türk Edebiyatı Tarihi: 1949 Yılına Ait Baskıdan 1956 Yılına Ait Baskıya Organizasyon, İçerik, Üslûp Farklılıkları*
}

\section{As an Example of Rewriting History of Turkish Literature in Nineteenth Century: Organization, Content, Style Differences from 1949 Edition to 1956 Edition}

\author{
Esra YALÇIN ${ }^{1}$ (i) Soner ÖZCAN ${ }^{2}$ (D)
}

*Bu çalıșma, 11 Mart 2017 tarihinde Tarih Vakfı tarafından gerçekleştirilen "Ahmet Hamdi Tanpınar ve XIX. Asır Türk Edebiyatı Tarihi'ni Yeniden Okumak" başııklı çalıştayda tarafımızca sunulmuş bildirinin genişletilmiş hâlidir.

'Sorumlu yazar/Corresponding author: Esra Yalçın (Doktora Öğrencisi),

Kocaeli Üniversitesi, Türk Dili ve Edebiyatı Bölümü, Kocaeli, Türkiye

E-posta: esrayalcin2@gmail.com ORCID: 0000-0001-7548-6293

${ }^{2}$ Soner Özcan (Bağımsız Araştırmacı), İstanbul, Türkiye.

E-posta: soner.ozcan34@gmail.com ORCID: 0000-0001-5380-1950

Başvuru/Submitted: 22.09 .2020 Revizyon Talebi/Revision Requested: 02.09.2020

Son Revizyon/Last Revision Received: 05.09.2020

Kabul/Accepted: 08.03.2021

Online Yayın/Published Online: 17.04.2021

Atıf/Citation: Yalcin, Esra ve Ozcan, Soner. "Bir Yeniden Yazım Örneği Olarak On Dokuzuncu Asır Türk Edebiyatı Tarihi: 1949 Yılına Ait Baskıdan 1956 Yilına Ait Baskıya Organizasyon, Içerik, Üslûp Farklılıkları." Türkiyat MecmuasıJournal of Turkology 31, 1 (2021): 401-423. https://doi.org/10.26650/iuturkiyat.788868

\section{öz}

Ahmet Hamdi Tanpınar'ın Türk Edebiyatı'nda Batılılaşma sürecini ele aldığı On Dokuzuncu Asır Türk Edebiyatı Tarihi adlı çalışmasının ilk formaları 1942 tarihinde basılır. 1943 yılında kitabın birinci cildinin tamamlanacağına inanan Tanpınar kalan bölümleri yazdıktan sonra kitabın basılmasına karar verir. Kalan bölümlerin yazılması ve birinci cilt olarak tasarlanan kitabın bitmesi 1949 yılını bulur. 1956 yılında ise bu kitabın gözden geçirilmiş ikinci baskısı yayımlanır. Ancak Tanpınar tarafından gerçekleştirilen bu gözden geçirme esnasında hem metnin organizasyonunda hem de ele alınan konuların mahiyetinde değişiklik yapılır. Bu durum, 1956 yılında yayımlanan ikinci baskıyı bir yeniden yazım olarak değerlendirmeyi mümkün kılar. Bu çalışmada On Dokuzuncu Asır Türk Edebiyatı Tarihi yeniden yazılırken metin üzerinde yapılmış değişikliklerin belirlenmesi hedeflenmiştir. Bu amaçla 1949 yılındaki baskı ile 1956 yılındaki baskı arasında Ahmet Hamdi Tanpınar tarafından yapılan değişiklikler sırasıyla organizasyon, içerik ve üslûp kategorileri altında bölümlenmiştir. İki baskı arasındaki farkların belirlenmesinin yazarın bu süreçte geçirdiği fikri dönüşümü göstermesi bakımından işlevsel olduğu düşünülmektedir.

Anahtar kelimeler: On dokuzuncu asır, Türk edebiyatı tarihi, Ahmet Hamdi Tanpınar

\section{ABSTRACT}

The first section of Ahmet Hamdi Tanpinar's History of Turkish Literature in Nineteenth Century, in which he studied the westernization of Turkish literature, was published in 1942. Believing that the first volume of the book would be completed in 1943, Tanpinar decided to publish the book after writing the remaining chapters. The remaining chapters and book that he considered the first volume of his study were completed in 1949. In 1956, the second revised edition of the book was published. However, during this revision the organization of the text and nature of the topics discussed were changed. The changes made it possible to consider the second edition, published in 1956, as a rewrite. In this study, it is aimed to compare the 1949 and 1956 editions of the History 
of Turkish Literature in Nineteenth Century and determine the differences. Therefore, the changes made by Tanpinar between the 1949 and 1956 editions were divided into categories of organization, content, and style. It is considered that determining the differences between the two editions is functional in terms of showing the intellectual/visional transformation of the author during the revision.

Keywords: Nineteenth century, history of Turkish literature, and Ahmet Hamdi Tanpinar

\section{EXTENDED ABSTRACT}

Ahmet Hamdi Tanpinar started teaching art history, aesthetics, and mythology at the Fine Arts Academy (Güzel Sanatlar Akademisi) in 1933. On the 100th anniversary of the declaration of the Gülhane Hatt-1 Hümâyunu (Imperial Edict of Gülhane) in 1939, the idea of establishing a new chair within the Faculty of Literature of Istanbul University to examine the changes in the period that Turkish literature had undergone with the Tanzimat was on the agenda. Hasan Âli Yücel, the minister of national education, appointed Tanpinar as a professor to the chair of Modern Turkish Literature in Istanbul University on November 15, 1939. Tanpinar, who had just taken up the position, was asked to prepare a scientific research book. It took him about 10 years to write the book.

First, Tanpinar planned to publish the History of Turkish Literature in Nineteenth Century one chapter at a time, as he wrote them. However, over time, he gave up the idea and waited to finish the entire book for publication. Therefore, when the initial chapters of the book were printed, the year 1942 was written on the inner cover of the 1949 edition. Publication of the book completed in 1949. In 1956, the second edition of the History of Turkish Literature in Nineteenth Century was published. In his review on this edition, Asaf Halet Çelebi drew attention to the fact that the 1956 edition was quite different from the 1949 edition and concluded that the 1956 edition was almost new work compared with the first one. However, Çelebi did not attempt to compare the editions completely.

In this study, we aimed to compare the 1949 and 1956 editions of the History of Turkish Literature in Nineteenth Century and determine the differences. The 1949, 1956, 1967, 2010, and 2016 editions of the book were scanned and compared. Quotations in the 1956 edition were taken from the most recent edition published by Dergâh Publications in 2006 owing to its easier access compared with other publications. However, as our main aim was to reveal the edits, additions, and deletions made by Tanpinar, the subsequent corrections in the Dergâh edition, such as those in date, writers' names, book titles, and the added bibliography part were not included in the comparison. In the study, the 1949 and 1956 editions were compared in terms of in-text organization, writing style, and content. We analyzed the differences between the two editions under three separate titles. For showing the changes in organization, we prepared tables as they provided a holistic view. We closely examined the expanded content of the 1956 edition that is more voluminous than the first edition. When both editions were analyzed in terms of writing style, we concluded that in this scientific research book, Tanpinar preserved his artistic writing style that he used in his novels and poems. In our conclusion, 
we made some predictions regarding the effects and thoughts under which the author made corrections in his work, by considering the differences, although the reasons for the changes made in the second edition could not be determined precisely. 


\section{Giriş}

Ahmet Hamdi Tanpınar, 1933 yılında Kadıköy Lisesi’nde edebiyat öğretmenliği yaparken Güzel Sanatlar Akademisi'nde sanat tarihi, estetik ve mitoloji derslerini vermeye başlamıştır. 1939 yılında Tanzimat Fermanı'nın ilanının 100’üncü yılı dolayısıyla İstanbul Üniversitesi Edebiyat Fakültesi bünyesinde Türk edebiyatının Tanzimat ile girdiği devreyi inceleyecek yeni bir kürsü kurulması fikri gündeme gelir. Maarif Vekili Hasan Âli Yücel, 1939 yılının Kasım ayının on beşinde İstanbul Üniversitesi Türk Dili ve Edebiyatı Yeni Edebiyat kürsüsüne Ahmet Hamdi Tanpınar'ı profesör olarak tayin eder. Bu atama edebiyat dünyasında çeşitli tartışmalara neden olur. ${ }^{1}$ Zira o döneme kadar Tanpınar'ın edebiyat tarihi hususunda yazılmış herhangi bir bilimsel çalışması yoktur. Yeni görevinin başına geçen Tanpınar için yapılacak ilk şeylerden birisi bilimsel nitelikli bir inceleme kitabı hazırlamaktır. Uzun bir hazırlık dönemi neticesinde kitabın yazılması yaklaşık on yılı bulur. Ömer Faruk Akün'ün belirttiği gibi Tanpınar, On Dokuzuncu Asır Türk Edebiyatı Tarihi'nde kullanacağı metodu belirlemek için Thibaudet'yi tekrar okumuştur. Onun nesiller ve Hippolyte Taine'in zaman ve çevre teorilerini eserinde kullanmıştır. Ahmet Cevdet Paşa'nın Tarih-i Cevdet'ini yeniden okuyup İbnülemin Mahmut Kemal İnal'ın meclislerine gitmiştir. Bütün bunlar yazılacak edebiyat tarihinin hazırlık çalışmalarıdır. ${ }^{2}$

Ahmet Hamdi Tanpınar, On Dokuzuncu Asır Türk Edebiyatı Tarihi’ni başlangıçta yazdıkça yayımlamayı planlar. Ancak zamanla bu fikrinden vazgeçer ve yayımlanması için kitabın tamamını bitirmeyi uygun bulur. Bu nedenle 1949 yılındaki baskının iç kapağında kitabın ilk formalarının basıldığı tarih olan 1942 tarihi yazılıdır. Kitabın tamamının basılması ise 1949 yılını bulmuştur. ${ }^{3}$

Edebiyat tarihinin tamamlanması uzun ve sancılı bir süreç hâlini alır. Yazarın edebiyat tarihi üzerine çalıştığı dönemde çevresine yazdığı kişisel mektuplarında bu sıkıntı açığa çıkmaktadır. Bunlardan biri Cevat Dursunoğlu'na yazdığı ve mebusluk isteğinden bahsettiği mektubudur: "Mektubum karışık oldu. Kusura bakmayın. Çok yorgunum. Bu Tanzimat kitabı, On Dokuzuncu Asır Türk Edebiyatı Tarihi beni çok yoruyor. Bu ayın sonunda ilk cildini bitirmiş olacă̆ım. Şimdiye kadar bir şöhret-i kâzibe hâlinde aranızda dolaştım. Hepiniz üzerimde bahse girdiniz. Ümit ederim ki sizi mahcup etmeyeceğim. Fakat çok yoruluyorum."

Bu mektup kendisinden bir edebiyat tarihi yazması beklenen Ahmet Hamdi Tanpınar'ın üzerinde hissettiği baskıyı göstermesi bakımından dikkate değerdir. 1944 yılında Mehmet Kaplan'a yazdığı iki mektupta da edebiyat tarihinin ilk formalarını dizdirmesi için Kaplan'a yönergeler verir. Tanpınar'ın bu kitap üzerine çalışmaya başladığı tarihten 1949 yılına kadar

1 Ömer Faruk Akün, “Ahmet Hamdi Tanpınar”, Türk Dili ve Edebiyatı Dergisi, XII, Aralık (1962), 1-32.

2 Akün, "Tanpınar", 12.

3 Orhan Okay, "Şiirler, Romanlar ve Akademik Yorgunluklar Arasında On Dokuzuncu Asır Türk Edebiyatı Tarihi”, Toplumbilim: Ahmet Hamdi Tanpinar Özel Sayısl 20, (1998), 14. 
araya pek çok şiir, makale, roman (Mahur Beste ve Huzur) girmiştir."5 Ancak 1949 yılında tamamlanıp basılabilen kitapta da bazı noktalarda eksiklik vardır. Bu durumu fark eden Tanpınar, "biyografik cetvellerin, kaynak kitap adlarının mündericat ve isim indekslerinin,

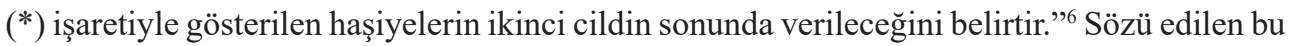
ikinci cilt tamamlanıp basılamamıştır. 1954 yılında yeni baskı için hazırlıklara girişen Tanpınar, İstanbul Üniversitesi dekanlığına verdiği bir dilekçede iki senedir edebiyat tarihinin değişmiş ve düzeltilmiş ikinci baskısı için uğraştığını belirtir."’

İlk baskı yayımlandıktan sonra kitapla ilgili tanıtıcı mahiyette yazılar yazılmıştır. Bunlar biri sonra 1949 yılı Haziran ayında Halil Vehbi Eralp'in Yeni Sabah gazetesinde yayımlanan yazısıdır. Tanpınar'ın şahsiyetler ve eserlerle ilgili vurucu sözlerine yer verdikten sonra henüz bilinmeyen bir devri kaleme alan bu kitapta kimi yanlışların bulunabileceğine vurgu yapar. Ona göre bu eseri değerli kılan yazarın "görüşlerindeki hususiyet ve üslubundaki mükemmelliktir." Aynı yıl Akşam gazetesinde Şevket Rado da "Bir Tenkit Hadisesi”" başlıklı bir tanıtım yazısı kaleme alır. Burada Rado, Tanzimat Devri edebî şahsiyetlerinin “Tanpınar'ın kendi zevki ve edebiyat tarihi anlayışı zaviyesinden" kaleme alındığına dikkat çeker." 1949 yılındaki baskı üzerine yazılmış her iki yazıda da Tanpınar'ın kendi şahsiyetini eserine yansıttığına vurgu yapılmıştır.

1956 yılında On Dokuzuncu Asır Türk Edebiyatı Tarihi'nin ikinci baskısı yapılır. Bu bask1 üzerine kaleme aldığı yazıda Asaf Halet Çelebi, 1956 yılına ait baskının 1949 yılına ait olan baskıdan oldukça farklı olduğuna dikkat çeker ve birincisiyle karşılaştırıldığında 1956 yılında yapılan baskının âdeta başlı başına yeni bir eser olduğuna kanaat getirir." ${ }^{10}$ Ancak Çelebi bu iki baskıyı karşılaştırma çabası içerisine girmez.

1956 yılında yayımlanan ikinci baskıda da eserin kaynakça kısmı yer almaz. Bunun yanında eserde bir kısmı yazardan bir kısmı ise matbaadan kaynaklanan çeşitli isim ve tarih yanlışlıkları bulunur. 1967 yılında Çağlayan Kitabevi tarafından çıkartılan üçüncü baskıya özel isim, eser, gazete ve dergi adlarını kapsayan bir indeks ilâve edilir. Ancak eser üzerinde en ayrıntılı ve dikkatli düzeltme Abdullah Uçman tarafından hazırlanan 2010 baskısıdır. Bu baskıda metnin imlâsı tek tip hâle getirilerek metin içi tutarlılık sağlanmış, kronoloji ve yazım yanlışlıkları düzeltilmiş, Tanpınar'ın dipnotlarda gösterdiği kaynaklarda eksik veya yanlışlık varsa giderilmiştir. Düzeltmeler metin içine (*) koyup dipnotta açıklama yoluyla ya da metin içinde köşeli parantez kullanılarak yapılmıştır. Böylelikle 1956 yılına ait baskıda yapılan düzeltmeler kolaylıkla tespit edilebilmektedir.

\footnotetext{
Okay, Türk Edebiyatı Tarihi, 16.

Okay, Türk Edebiyatı Tarihi, 17.

Okay, Türk Edebiyatı Tarihi, 17.

Eralp, H. Vehbi, “Ahmet Hamdi Tanpınar'ın On Dokuzuncu Asır Türk Edebiyatı Tarihi”, Yeni Sabah, (22 Haziran 1949), 2.

9 Şevket Rado, "Edebiyatımızda Bir Tenkit Hadisesi”" Akşam 10953, ( Nisan 1949), 2.

10 Asaf Halet Çelebi, “On Dokuzuncu Asır Türk Edebiyatı Tarihi” Türk Yurdu Dergisi 259, (Ağustos 1956), 151.
} 
On Dokuzuncu Asır Türk Edebiyatı Tarihi'nin 1949 yılındaki ve 1956 yılındaki baskılarını karşılaştıran ve farklılıkları tespit etmeyi hedefleyen bu çalışmada edebiyat tarihinin yayımlanan 1949, 1956, 1967, 2010 ve 2016 baskıları gözden geçirilerek karşılaştırıldı. 1956 yılına ait baskıdan yapılan alıntılar, ulaşılabilirlik açısından daha kolay olması nedeniyle en güncel baskı olan 2016 tarihli Dergâh Yayınları tarafından çıkan baskıdan yapıldı. Ancak temel hedefimiz Ahmet Hamdi Tanpınar'ın kendisi tarafindan yapılan düzenleme, ekleme ve çıkarmaları ortaya koymak olduğundan Dergâh Yayınları baskısındaki tarih, şahıs ve eser ismi düzeltmeleri ve eklenen kaynakça kısmı karşılaştırmaya dâhil edilmedi. Çalışmada 1949 yılına ait baskı ile 1956 yılına ait baskı metin içi organizasyon, üslûp ve içerik noktalarında karşılaştırıldı. Tespit edilen farklılıklar üç ayrı başlık altında incelendi. Organizasyondaki değişiklikleri göstermede bütünlüklü bir görünüm sağladığı için tablolardan yararlanıldı. Birinci baskıya göre daha hacimli olan 1956 yılına ait baskının genişletilmiş içeriği incelendi. Her iki baskı üslûp bağlamında incelendiğinde ise romanlarından ve şiirlerinden alışık olunan Tanpınar üslûbunun korunduğu görüldü. Sonuç bölümünde ise Tanpınar'ın ikinci baskıda yaptığı değişikliklerin nedenleri kesin olarak belirlenemese de farklılıklardan yola çıkarak yazarın hangi dinamiklerle eserinde düzeltmeler yaptığına dair öngörülerde bulunuldu.

\section{1949 Yılındaki Baskısından 1956 Yılındaki Baskısına Metnin Organizasyonundaki Değişim}

On Dokuzuncu Asır Türk Edebiyatı Tarihi Ahmet Hamdi Tanpınar'ın Tanzimat devrinden itibaren Türk Edebiyatında yenileşme sürecini anlatmayı hedeflediği bir edebiyat tarihi metnidir. Kitabın 1949 yılındaki baskısının sonunda yer alan "Birinci Cildin Sonu” yazısından anlaşıldığı üzere Tanpınar, bu edebiyat tarihi metnini iki cilt hâlinde yazmayı planlamıştır. Ancak ikinci cilt hiçbir zaman yazılamamıştır. 1956 yılında, Tanpınar 1949 yılında yayımlanan ilk baskı üzerinde pekçok değişiklik yapmıştır. Bunlardan ilk dikkat çekeni metnin organize edilişinde yapılan değişikliktir. İki baskı arasındaki bu organizasyon değişiklikleri başlıklandırmadaki farklılıklar ve kaynak gösterimindeki farklılıklar alt kategorilerinde incelenecektir.

\subsection{Başılıklandırmadaki Farklılıklar}

Ahmet Hamdi Tanpınar'ın bir medeniyet dairesinden başka bir medeniyet dairesine geçiş dönemi olarak gördüğü on dokuzuncu asırda edebiyat alanındaki değişim, devirdeki tarihsel olaylarla doğrudan bağlantılıdır. Bu durum bu devirdeki yazarları ve eserlerini incelemeye geçmeden önce tarihsel bir perspektifin çizilmesini zorunlu kılmıştır. Her iki basımda da Batılılaşma süreci tarihsel arka plan göz önünde tutularak ele alınmıştır. Özellikle "XIX. Asrın İlk Yarısında Türk Edebiyatı” başlıklı birinci bölüme kadar Osmanlı Devleti'nde yaşanan Batılılaşma süreci tarihî bir süreç olarak anlatılır. Mehmet Kaplan, 1949 yılında kitabın ilk baskısının yayımlanması üzerine yazdığı tanıtım yazısında On Dokuzuncu Asır Türk Edebiyatı Tarihi'nin "mevzuunu geniş bir mahiyet içerisinde umumi tarih, devir, nesil, şahsiyet ve eser 
bakımından hiç aksatmadan tahlilî ve terkibî bir düşünce ile" kaleme aldığına dikkat çeker. ${ }^{11} 1949$ yılındaki baskısı için yapılan bu yorum 1956 yılındaki baskısı için de geçerliliğini korumuştur.

On Dokuzuncu Asır Türk Edebiyatı Tarihi'nin 1949 yılında yayımlanan ilk baskısı “Garplılaşma Hareketine Umumi Bir Bakış" başlıklı Tanzimat Devrinin siyasi ve sosyal koşullarını hazırlayan gelişmelerin anlatıldığı bölüm ile başlar ve Abdülhak Hamid'in anlatıldığ bir "Giriş" bölümü ile başlar. Bu bölümde Tanpınar, Eski Türk Edebiyatına dair orijinal görüşlerine yer verir. Ömer Faruk Akün’e göre bu bölüm Tanpınar'ın 1930 yılında Ankara' da gerçekleştirilen Edebiyat Muallimleri Kongresinden beri üzerine düşündüğü, geliştirdiği, daha sağlam ölçülerle değerlendirdiği fikirlerinin son hâlidir. Akün, bu giriş kısmını 1956 yılındaki baskının Türk Edebiyatı'na getirdiği en büyük kazanç olarak değerlendirir. ${ }^{12} 1949$ yılına ait baskının ilk bölümü olan "Garplılaşma Hareketine Umumi Bir Bakış” başlıklı bölüm aynı zamanda "Giriş” bölümü olarak adlandırılmıştır. 1956 yılındaki baskıda ise yeni bir giriş kısmı hazırlandığı için “Garplılaşma Hareketine Umumi Bir Bakış” bölümü metnin giriş bölümü olarak değerlendirilmemiş bir sonraki bölüm olarak metne yerleştirilmişstir.

Bugün On Dokuzuncu Asır Türk Edebiyatı Tarihi olarak bilinen metin, çoğunlukla 1956 yılında Tanpınar tarafından gözden geçirilerek oluşturulan ve aslında yeniden yazılan 2 . baskısıdır. Çalışmanın bu kısmında ilk olarak 1956 yılına ait baskının genel yapısı ortaya konulacak daha sonra 1949 yılındaki baskı ile karşılaştırılacaktır.

1956 yılındaki baskının “Garplılaşma Hareketine Umumi Bir Bakış” bölümünde Lale Devri’nden Tanzimat Devri’ne kadar uzanan süreçte Batılılaşma hareketi ele alınır. Daha sonra “'On Dokuzuncu Asırda Türk Edebiyatı" başlıklı bir bölüm açılır. Bu bölüm kendi içerisinde iki kısma ayrılır. "19. Asrın İlk Yarısında Türk Edebiyatı” başlığını taşıyan birinci bölümde Divan şiiri ve Halk şiiri örnekleriyle birlikte ele alınır. İkinci kısım ise "Tanzimat Seneleri” başlığını taşır. Bu bölümde İstanbul' da yaşamın değişmesi, Batıya açılmayla gelişen ve değişen fikir hayatı, yeni giren makale, gazete gibi edebî türler hakkında bilgi verilir. "Yeniliğin Üç Büyük Muharriri”" başlı̆ğ altında ise Ahmet Cevdet Paşa, Münif Paşa ve Şinasi üzerinde durulur. "Şinasi’den Sonra Yeni Osmanlılar" başlığı altında ise devrin siyasi koşulları ortaya konur. Bu kısımda Ali Suavi’ye özel bir yer ayrılmıştır. “Nevilerin Gelişimi”’ bölümünde batıdan giren edebî türler tanıtılır. Gazete ve gazetecilik, şiirdeki farklılık, tiyatro, hikâye gibi edebî türler hakkında bilgi verilir. Daha sonra ise eserleri ve fikirleriyle Tanzimat Devri fikir ve sanat anlayışının oluşmasına etki eden şahısların biyografilerine, eserlerine, edebî ve fikrî yönlerine yer verilir. Bu şahıslar, Ziya Paşa, Namık Kemal, Ahmet Mithat Efendi, Recaizade Mahmut Ekrem, Abdülhak Hamid ve Muallim Naci'dir.

1949 yılındaki baskının bölümlenme biçimine bakıldığında ilk dikkati çeken, kitabın üç ayrı bölüm olarak tasarlanmasıdır. "Yirminci Asır Türk Edebiyatı Tarihi” başlıklı ilk bölümde 19. asrın ilk yarımından, Tanzimat Fermanı'nın yayımlandığg 1839’a kadarki süreçte şiir ve

11 Mehmet Kaplan, “On Dokuzuncu Asır Türk Edebiyatı Tarihi”, Şadırvan: Haftalık Sanat Mecmuası 1:9 (27 Mayis 1949), 7.

12 Akün, "Tanpınar", 15. 
nesirde meydana gelen değişikliklerden bahsedilmiştir. Bu bölümde on dokuzuncu asır Osmanlı şiiri ve nesri hakkında genel bilgiler verilmiş ancak ayrıntılı şiir analizlerinde bulunulmamıştır. On Dokuzuncu Asır Türk Edebiyatı Tarihi asıl ağırlığını Tanzimat'ın ilan edilmesiyle yaşanan değişiklikler ve bunun devrin edebiyatına yansıması oluşturur. Bu nedenle en uzun bölüm “Tanzimat Seneleri” şeklinde başlıklandırılan ikinci bölüm olmuştur. 1956 yılına ait baskıda benzer şekilde "Tanzimat Seneleri” şeklinde başlıklandırılan ikinci bölüm ise 1949 yılındaki baskıya göre daha geniş bir içeriğe sahiptir. Çünkü 1949 yılındaki baskıda üçüncü bölüm olarak belirlenen "Şahıslar ve Eserler” kısmı 1956 yılına ait baskıda müstakil bir bölüm oluşturmaz. Ziya Paşa, Namık Kemal, Recaizade gibi devrin önde gelen şair ve yazarlarının tanıtıldığı bu kısım 1956 yılına ait baskıda "Tanzimat Seneleri” üst başlığı altında verilirken 1949 yılına ait baskıda "Üçüncü Bölüm: Şahıslar ve Eserler” üst başlığı içerisinde değerlendirilir.

1956 yılında yapılan baskıda Tanzimat Devri senelerinin ele alındığı kısımda “1839’dan 1860’a Kadar” ve "1856-1876 Yılları" şeklinde iki ayrı alt bölüm vardır. 1949 yılındaki baskıda ise bu bölümlendirme şu şekildedir: “1839’dan 1858'e Kadar” ve “1860-1876 Y1lları”. Ahmet Hamdi Tanpınar 1860 yılını bir sınır olarak belirlemesinin nedenini 1949 yılına ait baskıda şöyle açıklar:

1960 senesini kitabımızın bölümünde bir had gibi almamızın bir çok sebepleri vardır. Fakat en başlıcası tanzimatın 1858, 1860 seneleri arasında ilk safhasını kapatması ve daha çok Garplı olan ikinci safhasına girmesidir. 1858 'de Reşid Paşa 1860'da Abdülmecid Han ölürler. Sonuncusu daha ziyade temsili mahiyette olan bu iki ölümün asıl manası bir anlayış tarzının hayattan çekilmesi demektir. II. Mahmut'un yenileşme anlayışının cemiyet ve devlet hayatında şuurlaşması olan bu zihniyet, Şarkla Garbın -çok acele olmakla beraber- bir terkibini arıyor ve yerli hayatın çerçevesini lüzumundan fazla bozmadan asrın ihtiyaçlarına uymaya çalışıordu. Garba olan iştiyakı ne olursa olsun eski hayatımıza ve ananelerimize şiddetle bağlıydı. Doğrusu istenilirse Şinasi Asya'nın aklı piranesi ile Avrupa'nın bikr-i fikrini birleştirmek şeklindeki düsturunu koyarken az çok bu zihniyetin ağzından konuşur; onun hayat ve istikbal karşısındaki duruşunu tespit eder. 1860-1876 arasında hayata istikamet verenler ise Reşid Paşa devrinde yetişenler, siyasi terbiyelerini o zamanda yapanlardır. ${ }^{13}$

1956 yılındaki baskıda ise bu bölüm Islahat Fermanı temel alınarak "1856-1876 Yı1ları" şeklinde düzenlenmiştir. Tanpınar 1956 yılındaki baskıda Islahat Fermanı’nın bir sınır olarak belirlenmesinin nedenini ise şöyle açıklar:

$\mathrm{Bu}$ fermanla yeni bir nesil, çok acemice ve acele olsa bile, ilk defa olarak kendi adlarına konuşurlar. Filhakika bu fermanla, Âli ve Fuad Paşalar, artık Reşid Paşa mektebinin talebeleri ve onun yakın iş arkadaşları olmaktan çıkarlar; Gülhane Hattı'ndan daha mühim ve değiştirici bir devrin mesuliyetini kendi başlarına yüklenirler. Bu, bir bakıma, sekiz sene sonra Namık Kemal'in Şinasi'nin yanı başında ve yirmi sene sonra da Hâmid'in Namık Kemal'in yanı başında konuşmasına benzer. ${ }^{14}$

13 Ahmet Hamdi Tanpınar, On Dokuzuncu Asır Türk Edebiyatı Tarihi ( İstanbul: Üçler Basımevi, 1949), s.107.

14 Ahmet Hamdi Tanpınar, On Dokuzuncu Asır Türk Edebiyatı Tarihi (İstanbul: DergâhYayınları, 2016 ), 158. 
Ahmet Hamdi Tanpınar, 1956 yılına ait baskıda Islahat Fermanı'nın önemine dikkat çekmiş ve kitabın bölümlendirilmesinde bu fermanın tarihinin dikkate alındığını belirtmiştir. Ona göre bu fermanla beraber "yeni bir nesil çok acemice ve acele olsa bile ilk defa kendi adlarına konuşurlar" 15 bu fermanla Âli ve Fuat Paşa'lar Reşid Paşa'nın talebeleri olmaktan çıkar ve devrin mesûliyetini tek başlarına yüklenirler. Tanpınar'a göre Namık Kemal'in Şinasi'den sekiz yıl sonra onun yanı başında ve yirmi sene sonra da Hâmid'in Namık Kemal'in yanı başında sesleri duyulur. Tanpınar 1956 yılındaki baskıda sesi cılız çıkan bu nesli önemser ve kitabın bölümlendirilmesini buna göre yapar. 1949 yılına ait baskıda bölümler kişiler merkeze alınarak ayrılmazken 1956 yılına ait baskıda İbrahim Şinasi’nin anlatıldığı kısımdan itibaren “Şinasi'den Sonra Yeni Osmanlılar Cemiyeti”, "Şinasi’den Sonra Nevilerin Gelişmesi”, "Şinasi'nin Yanı başında Ziya Paşa”, "Şinasi’den Sonra Namık Kemal”, "Namık Kemal'in Yanı Başında Ahmed Midhat Efendi”, "Namık Kemal'den Sonra Recaizâde Mahmud Ekrem Bey”, "Namık Kemal'den Sonra Abdülhak Hâmid” şeklinde kişileri esas alan bir başlıklandırma yapılmıştır. Bölümlerin içeriklerinde büyük değişiklikler yapılmasa da edebî şahsiyetlerin kitabın bölümlendirilmesinde ölçüt olarak seçilmesi önceki baskıya göre yazar ve şairlerin daha çok ön plana alındığını düşündürmektedir. Bunun yanında 1956 yılındaki baskıda şairlere ayrılan müstakil bölümler kendi aralarında alt başlıklara bölünürken de benzer şekilde "Şinasi ve Namık Kemal” temel alınmıştır. Örneğin Namık Kemal'e ayrılan bölümünün alt başlıkları şu şekildedir: 1. Hayatı: Şinasi'den Evvel / Şinasi ile Tanışma / Her Şeyden Evvel Nesir / Gazete ve meseleler / Kemal Paris'te 2. Şiirleri: Şinasi'den Evvel / Şinasi'den sonra

1949 yılına ait baskıda ise Şinasi’ye ayrılan kısımda doğrudan “hayatı ve şiirleri” şeklinde bir bölümlenme vardır. Bu değişikliğin sebebinin edebiyatın modernleşmesi sürecinde Şinasi’ye atfedilen değerin değişmesi olduğu söylenebilir. Zira 1949 yılındaki baskıda Şinasi için söyle denilmektedir: "Edebiyatımızın ondan sonraki gelişmelerini tamamıyla onun hesabına geçirmek elbette ki haksızlıktır. Zaten hiçbir edebiyat veya sanatta yenilik ihtilâl tek bir insanın eseri olamaz. O her zaman devrin malıdır. Fakat bir veya birkaç kişi ufuk açar, Şinasi bir ufuk açıcı adamdır."16 1949 yılına ait baskıda Şinasi için "Filhakika eski nesre, murassâ ve fikrî bir süs tufanında boğan yahut da herhangi bir salâbetten ve nizamdan mahrum olarak konuşan nesrimize, bir yazı dili haysiyetini verenlerin başında değilse bile arasındadır." denilmektedir. ${ }^{17}$ 1956 yılındaki baskıda ise Şinasi yenileşme devrinin kapısını açan kişi olarak çizilir. 1949 yılındaki baskıda sanatta ve edebiyatta yenilik tek bir kişinin eseri olamaz denirken 1956 yılına ait baskıda yeni nesir tamamıyla Şinasi’nin eseri olarak görülür.

“İlahi”si ile, Lamartine tercümesi ve masalı ile, öbür tecrübeleriyle yeni şiirin kapısını açar. Tiyatro onunla gelir. Şark edebiyatlarının en büyük noksanı olan nesir ise, doğrudan doğruya onun eseridir. Türk cemiyetinde fikir, yine onunla başlar. Filhakika eski nesre, fikrî bir süs tufanında boğan, yahut da herhangi bir salâbetten ve nizamdan mahrum olarak konuşan

15 Tanpinar, On Dokuzuncu Asır (2016), 158.

16 Tanpinar, On Dokuzuncu Asır (1949), 153.

17 Tanpınar, On Dokuzuncu Asır (1949), 138. 
nesrimize, bir yazı dili haysiyetini verenlerin başında mutlak surette o vardır. Nesir onunla başlar. $^{18}$

İki baskı arasındaki içerik farklılıklarının incelendiği kısımda daha ayrıntılı ele alınacak olan Şinasi’ye yönelik bu farklılaşma kitabın organizasyonunu da değişime uğratmıştır. Temel bölümlendirmeye yönelik bu farklılaşmanın yanında alt başlıkların organizasyonunda da iki baskı arasında farklılıklar görülmektedir. 1949 yılına ait baskıda Romen rakamları ile verilen alt başlıklar, 1956 yılına ait baskıda müstakil başlıklarla ayrılmıştır. Bu durum Tanpınar'ın 1956 yılındaki baskıyı kaleme alırken 1949 yılındaki baskıya göre daha sistemli hareket ettiğini gösterir. Dolayısıyla 1956 yılına ait baskının bilimsel bir yazıdan beklenen özellikleri 1949 yılındaki baskıya göre daha fazla ihtiva ettiği ileri sürülebilir. 1949 yılına ait baskıda alt başlıklandırma noktasında titiz davranılmaz, 1956 yılındaki baskıda ise bu durum düzeltilir. Kitapta İbrahim Şinasi’ye ayrılan kısım iki baskı arasındaki bu değişimi göstermesi bakımından işlevseldir:

\begin{tabular}{ll}
$\mathbf{1 9 4 9}$ Yılındaki Baskı & $\mathbf{1 9 5 6}$ Yılındaki Baskı \\
\hline $\mathbf{3}$ & \\
İbrahim Şinasi Efendi & III - İbrahim Şinasi Efendi \\
I & 1. Hayatı, \\
II & 2. Bütünüyle Şinasi \\
III & 3. Şinasi’nin şiiri \\
VI Şair Evlenmesi & 4. Şair Evlenmesi \\
V & 5. Şinasi ve dil \\
VI & 6. Şinasi gazeteci \\
\hline
\end{tabular}

Bu durum kitabın sadece Şinasi’ye ayrılan kısmında değil pek çok kısmında bu şekildedir. 1949 yılına ait baskıda aceleye gelmiş gibi görünen bölümlendirme, 1956 yılındaki baskısında sistemli bir hâl alır.

\subsubsection{Kaynak Gösterimindeki Farklılıklar}

1949 yılına ait baskının kısmen aceleye gelmesi kısmen de Tanpınar'ın kendi yazım şekli nedeniyle kaynak gösterimi konusunda problemlidir. 1956 yılındaki baskısında gördüğümüz dipnotlandırma kitabın 1949 yılındaki baskısında sistemli değildir. Tanpınar, yazarın ve eserin ismine metin içerisinde yer verdiğinde çoğunlukla bu esere ait künyeyi dipnot ile bildirmez. İkincil kaynaklardan yapılan alıntılar metinle bütünleştirilerek verilir.

“d'Ohsson'un yirmi senelik bir gayret ve çalışma ile hazırladığı Tableau général de l'Empire Ottoman adlı büyük kitabı ile Melling'in o harikulade desenlerinin teşkil ettiği muazzam eserdir." (s.24)
Le voyage pittoresque de Constantinople et des rives du Bosphore, d'aprés les dessins de M. Melling, arc hitecte de l'Empereur Selim III et dessinateur de la Sultane Hadidgé, sa sœur, Paris 1819

18 Tanpınar, On Dokuzuncu Asır (2016), 195. 
"Namık Kemal eski şiir hakkındaki istitratlarından birinde

Tahrib-i Harabat'ta) Vasıf'ın şiirimizde yapmak istediği değişikliten bahsederken o da kendi kendine ve zamanın şive-i tekellümüne mutabık surette...)

Bazı kısımlarda alıntılara ait kitaplar veya yazarları metin içerisinde dahi yer almaz. Ahmet Hamdi Tanpınar bu kısımlarda ikincil kaynaklardan aldığı verileri kendi üslûbu ile aktarır. 1956 yılına ait baskıda metin aynen korunmuş ancak dipnot ile gerekli açıklamalar yapılmıştır.

\section{Baskısı}

"Cevdet Paşa'nıın dediğine göre Mahmut II devrinde âdeta vükelanın iltimasıyle...." İçerik aynı ancak metin içerisinde dahi kaynak belirtilmemiş.

"Hekimbaşı Abdülhak Molla’nın oğlu müverrih Hayrullah Efendi'nin Hikâye-i İbrahim Paşa be-İbrahim-i Gülşenî adlı eseri, vakıa neşredil mediği için Türk tiyatrosunun müstakbel inkişafı üzerine tesir etmiş değildir.” (s.105)

“Ölüm döşeğindeki karısını, hususi doktoru Spitzer'e ancak yüzü örtülü olarak

Gösterecek kadar efkâr-1 umumiyenin tenkidinden çekinen genç hükümdarın..." (s.87)
1956 Baskısı

Cevdet Paşa, Mâruzât, Türk Tarih Encümeni

Mecmuas1

Türklük Mecmuası, II, nr. 8, s.77-91

Ahmed Hamdi Tanpınar, “Âkif Paşa”, İA, I, s. 243 vd. ve mehazlar1.

Ahmet Refik, "Sultan Abdülmecid Han'ın Sarayında: Doktor Spitzer'in Hâtırâtı," Tarih-i Osmanî Encümeni Mecmuası, VI, nr. 34, 1915, s.614.

Buna dair fazla izahat için bk. Ebul'ulâ Mardin, Medeni Hukuk Cephesinden Ahmet Cevdet Paşa, s. $46 \mathrm{vd}$.

Bunun yanında 1956 yılındaki baskıda dipnotlarda, metin içinde verilen bilgilerle ilgili ikincil kaynaklara da yer verilmiştir. 1949 yılındaki baskıda bu şekilde, ele alınan mevzuu ile ilgili başvurulabilecek eserler listesi yer almaz. 1956 yılındaki baskıda bazı dipnotlarda ise metin içerisinde olmayan bilgi ve açıklamalara da yer verilir. Asıl metne ek olarak yapılan bu açıklamalar, 1949 yılında yapılan baskıda yer almaz. Kaynak gösterimindeki farklılıklar ve 1956 yılındaki baskı için başvurulan kaynaklardaki çeşitlilik Tanpınar'ın 1949 yılından 1956 yılına kadar geçen süre içerisinde edebiyat tarihine malzeme olabilecek nitelikteki okumalarını çoğalttığını düşündürmektedir. Zira hem başlık organizasyonundaki değişim hem de kaynak gösterimi ve başvurulan kaynakların niceliğindeki değişimden hareketle On Dokuzuncu Asır Türk Edebiyatı Tarihi'nin 1956 yılındaki baskısının 1949 yılındaki baskısına göre daha fazla akademik disiplin içerisinde olma çabasıyla yazıldığı ileri sürülebilir.

\section{1949 Yılındaki Baskısından 1956 Yılındaki Baskısına Metnin İçeriğindeki Değişim}

1949'dan 1956'a gelindiğinde Ahmet Hamdi Tanpınar'ın On Dokuzuncu Asır Türk Edebiyatı Tarihi içeriğinde de oldukça fazla değişiklik yaptığı görülmektedir. Özellikle "Tanzimat 
Seneleri” başlığını taşıyan ikinci bölümde içerik genişletilmiştir. Ahmet Hamdi Tanpınar, 1949 yılındaki baskıda yazarların ve şairlerin biyografilerine çok fazla yer vermemiştir. Bunun nedeninin Tanpınar'ın On Dokuzuncu Asır Türk Edebiyatı Tarihi'ni kendisinden beklenen sürede tamamlamaya çalışması olduğu ileri sürülebilir. Ahmet Hamdi Tanpınar, 1956 yılındaki baskıda, ele aldığı şairlerin ve yazarların hayat hikâyeleri hakkında 1949 yılındaki baskıya göre daha fazla bilgiye yer verir. Şinasi, Ziya Paşa ve Recaizade Mahmut Ekrem Bey’in biyografilerindeki genişleme özellikle dikkate değerdir. Ahmet Mithat Efendi ve Muallim Naci'yi ele alan kısımlar ise 1949 yılına ait baskıda olmayıp 1956' da eklenmiştir.

Ahmet Hamdi Tanpınar'ın Şinasi'nin hayatını anlattığı kısım bu noktada incelenmeye değerdir. Tanpınar 1956 yılına ait baskıda Şinasi’nin azalıktan azli meselesini daha geniş incelemiş ve ardından 1949 yılı baskısında "Bu azil ve tekrar tayin keyfiyetleri istisna edilirse, ikinci Avrupa seyahatine (1865) kadar, Tercüman-l Ahval'i (1860) ve sonra da Tasvir-i Efkar'1 (1862) çıkarmasından başka hayatında ehemmiyetli bir vaka yok gibidir." ${ }^{19}$ diyerek geçiştirdiği 1859-1865 yılları arası için iki sayfadan fazla açıklama eklemiştir. Benzer bir değişim Ziya Paşa'nın ele alındığı bölüm için de söz konusudur. Kitabın 1949 yılındaki baskısında Tanpınar'ın, Ziya Paşa'yı anlatırken ziyâdesiyle İbnülemin Mahmud Kemal İnal'ın Son Asır Türk Şairleri (ve Kaynakları) eserinden yararlandığı ileri sürülebilir. Hatta bir defaya mahsus olarak Süleyman Nazif'in İki Dost'una ve bir defa da Cevdet Paşa'nın Tezakir'ine verilen referans sayılmazsa Tanpınar ikincil kaynak olarak başka bir isme yer vermez. 1956 yılındaki baskısında ise bu bölüm, anılan daha çok kaynakla birlikte daha ayrıntılı olarak incelenmiştir. Ziya Paşa'nın Emile Mukaddimesi 'ne, Cevdet Paşa'nın Tezakir'ine ve Mâruzât'ına dayanılarak metne yeni cümleler eklenir. Bunun yanı sıra 1956 yılına ait baskıda sık sık Ebüzziya'ya referans düşülmesi de dikkat çekicidir. 1949 yılındaki baskısında, Ziya Paşa'nın hayatına dair malumatta Ebüzziya Tevfik'in adı hiç anılmazken, 1956 yılı baskısında onun Yeni Osmanlılar Tarihi adlı çalışmasından oldukça yararlanılır. Üstelik daha önce İbnülemin Mahmud Kemal İnal'a dayanılarak yazılan cümleler Ebüzziya'dan alıntılarla yeniden düzenlenir: “Ali Paşa ile işbirliği’ yapmağa kalkar. Paşa bu arzi hizmeti reddedince aleyhinde bulunur; hatta kendisi Ali Paşa'nın azlinde tesiri olduğuna ve Fuad Paşanın sadrazamlığında da Padişaha onun lehinde söylediği sözlerin bir hissesi bulunduğuna inanırmış." 20

1949 yılına ait baskısından alınmış yukarıdaki kısım, kitabın 1956 yılındaki baskısında Ebüzziya Tevfik' in Yeni Osmanlılar Tarihi'ne referansla yeniden düzenlenip genişletilmiştir. Ziya Paşa'nın hayatına dair bilgiler 1956 yılına ait baskıda şu şekilde aktarılmıştır:

Filhakika bütün kaynaklar Ali Paşa'nın 1861'de sadaretten azli meselesinde onun mühim bir rol oynadığında az çok birleşirler. Aşağı yukarı ilk biyografı olan Ebüzziya Tevfik ise bu hususta hepsinden kat'îdir. Yeni Osmanlılar Tarihi'ne göre Ziya Bey, padişahın Ali Paşa'ya karşı, akrabasından olan Zîver Paşa'yı Emîrü'l-hac yaptırdıktan sonra ayrıca da parasızlığından bahsederek kendisine "1500 kese akçe atiye ihsan" edilmesini istemesi

19 Tanpinar, On Dokuzuncu Asır (1949), 136.

20 Tanpınar, On Dokuzuncu Asır (1949), 217. 
üzerine artan hiddetinden istifade ederek "onu azil" ve "yerine o tarihte Suriye meselesinden dolayı iki senedir Şam'da bulunan Fuad Paşa'yı nasb'ettirir. ${ }^{21}$

Ahmet Hamdi Tanpınar'ın Ziya Paşa'dan sonra incelediği Namık Kemal'in biyografisinde ise iki baskı arasında içerik bakımından daha az değişiklik vardır. Nitekim Namık Kemal'e ayrılan kısım 1949 yılındaki baskıda da hacimli bir yer tutar, referans ve kaynakça açısından ele alınan diğer şahsiyetlere göre daha zengindir. Diğer yazar ve şairlere nazaran kitabın en hacimli incelemesi de yine Namık Kemal üzerinedir. Bu noktada Tanpınar'ın 1942 yılında Namık Kemal Antolojisi'ni yayımladığını hatırlamakta yarar var. Antoloji’nin girişindeki “Namık Kemal'in Hayatı ve Eserleri" bölümünün On Dokuzuncu Asır Türk Edebiyatı Tarihi'ndeki Namık Kemal bölümünün nüvesi olduğu söylenebilir. Üstelik ikisinin de ilk paragrafları hemen hemen aynıdır: "Hayatında hâkim ikinci vasıf erken inkişaftır; on dört yaşında şiire başlar, on altı yaşında evlenir, yirmi dört, yirmi beş yaşlarında ise şöhret ve şahsiyet sahibidir."22 $O n$ Dokuzuncu Asır Türk Edebiyatı Tarihi içerisindeki kısım ise şöyle başlar: "Namık Kemal'in hayatında dikkat edilmesi gereken taraf erken inkişafıdır. On altı, on yedi yaşlarında evlenir. Şiire ise daha evvel başlar. Yirmi bir, yirmi iki yaşlarında mürettep bir divan sahibidir. Yirmi beş yaşında devrinin hakikaten şöhret ve şahsiyet sahibi en ileri muharriridir." ${ }^{23} 1956$ yılındaki baskıda ise çok az bir değişiklikle şöyle başlanmıştır: "Namık Kemal Sofya'da on altı yaşında iken evlenmiştir. Zaten onda her şey böyle erkendir. On dört yaşında iken bir defter dolusu şiiri bulunacaktır. Yirmi iki yaşında divan sahibidir. Yirmi beş yaşında devrin en meşhur imzası olarak tanılır."24

Her üç metnin giriş kısımlarındaki bu benzerlik metnin tamamında da tespit edilebilir. 1949 yılına ait baskıda neredeyse doğrudan doğruya kullanılan Namık Kemal antolojisindeki bilgiler 1956 yılındaki baskıya da değiştirilmeden geçirilmiştir. Dolayısıyla On Dokuzuncu Asır Türk Edebiyatı Tarihi'nin Namık Kemal bölümünün çekirdeğini 1942 yılında yayımlanan Namık Kemal Antolojisi'nin oluşturduğu söylenebilir.

Ahmet Hamdi Tanpınar'ın 1956 yılındaki baskıda biyografisini genişlettiği bir diğer isim Recaizade Mahmut Ekrem'dir. 1949 yılına ait baskıda Recaizade Mahmut Ekrem ile ilgili "Biyografisi üzerinde fazla ısrar etmememizin sebebi eserine tesiri olmamasıdır. O Ziya Paşa ve Namık Kemal gibi çok şahsi bir maceranın sahibi değildir. Onun hayatı eserlerinin ve memuriyetlerinin hikâyesidir. Belli başlı tarihleriyle bunu vermek kâfidir." 25 şeklinde bir açıklama yeterli bulunmuştur. 1956 yılına ait baskıda ise Tanpınar bu cümleyi çıkarmış ve yazarın hayat hikâyesini genel hatlarıyla ele almıştır. Benzer şekilde 1949 yılına ait baskıda Recaizade Ekrem Bey'in hikâyelerini ve tiyatrolarını incelerken "Ekrem Beyin ne Şemsa (1869) ve ne de Muhsin Bey - yahut - Şairliğin Hazin bir Neticesi (1889) adlı hikâyeleri üzerinde

21 Tanpınar, On Dokuzuncu Asır (2016), 302.

22 Ahmet Hamdi Tanpınar, Namık Kemal Antolojisi (İstanbul: Muallim Ahmed Halim Kütüphanesi, 1942 ), 5.

23 Tanpinar, On Dokuzuncu Asır (1949), 256.

24 Tanpinar, On Dokuzuncu Asir (2016), 341.

25 Tanpınar, On Dokuzuncu Asır (1949), 365. 
durulacak eserler değildir." ${ }^{26}$ denilerek bu metinler incelenmemiştir. 1956 yılındaki baskısında ise bu eserler ayrıca ele alınmış ve ayrıntılı olmasa da eserlerle ilgili bilgi verilmiştir.

1949 yılındaki baskıdan 1956 yılındaki baskıya yalnız biyografilerde değil, ele alınan şair ve yazarların incelenen eserlerinde özellikle şiirlerin sayılarında da artış görülür. 1956 yılındaki baskıda eklenen şiirlere örnek olarak şunlar verilebilir: "Bahrın bu şeb emvâc-1 safâ aştı boyundan / Vâsıf binelim kayığa İstinye koyundan / Sâgar çekerek zevk ile Kandilli suyundan / Göksû'ya gel ey çeşm-i kebûd âlem-i âb et", "Ümîd-i mağfiretle dergeh-i ihsânına geldim / Günâhım yüklenip mânend-i merkeb yâ Resûlallah (Enderunlu Vasıf) ${ }^{27}$

1956 yılındaki baskıda Şinasi’nin şiir anlayışının ele alındığı kısımda 1949 yılına ait baskıya oranla daha fazla şiir örneğine yer verilmiştir. Bunun yanında sadece verilen şiir örneklerindeki niceliksel artış değil, bu şiirler üzerine geliştirilen tespitler de 1956 yılındaki baskıda genişletilmiştir.

Şinasi Divançesi'nde, bu noktadan çok ehemmiyetli bir eser de, Nef'î'nin meşhur:

Sanman ki felek devr ile şâmı seher eyler

Her vakıanın âkıbetinden haber eyler

matla'lı kasidesinin yedi beytine yaptığı naziredir ki, üçüncü beyitten itibaren Nef'̂̀’nin eskiler için tabii olan fatalizmini,

Hak yol aramak vâcibedir akl-1 selîme

Tevfîkini isterse Hudâ râhber eyler

Mahrum ise tevfîkin eğer fâidesinden

Ya aczini gördükçe mi âkil zarar eyler

Her vakıa bir ders-i hikemdir nazarında

Her derd ü belâdan dahi ahz-i iber eyler

mısralarıyla karşılar. Ne zaman yazıldığını bilmediğimiz, fakat divanındaki gazel nazirelerinden sonra olduğunu tahmin ettiğimiz bu nazire ile Şinasi daha sarih ve daha bütün konuşur. Bu nazirenin hakiki mânası insanın kader karşısında, yani biraz da kendi içinde hürriyetidir. ${ }^{28}$

1949 yılındaki baskıda yer almayıp 1956 yılına ait baskıda yer ver alan şiirlerin sayısını arttırmak mümkündür. Yazar sadece örnekleri artırmamış, ele aldığı metinler üzerinde dikkatle durarak onları çözümlemeye çalışmıştır. Bütün bunlar Ahmet Hamdi Tanpınar'ın 1949 yılından 1956 yılına kadar geçen sürede On Dokuzuncu Asır Türk Edebiyatı Tarihi metnini içerik olarak oldukça genişlettiğini, metne yeni kaynaklar ve bilgiler eklediğini gösterir. Bu durum eserin iki baskısı arasında geçen sürede yazarın ele aldığı konularla ilgili okumalarını genişlettiğini ve kitapta yer verdiği şair ve yazarların eserlerini daha ayrıntılı incelediğini düşündürmektedir.

26 Tanpınar, On Dokuzuncu Asır (1949), 375.

27 Tanpinar, On Dokuzuncu Asir (2016), 94.

28 Tanpınar, On Dokuzuncu Asır (2016), 203. 
On Dokuzuncu Asır Türk Edebiyatı Tarihi'nin her iki nüshasında da ele alınan dönem on dokuzuncu asırla sınırlı tutulmuş, bu devre kadar olan süreçte Türk edebiyatı dünyasında yaşananlar ve on dokuzuncu asırdaki Türk edebiyatını hazırlayan dinamiklere değinilmemiştir. "Edebiyat Tairhine Manifestik Bir Bakış" adlı yazısında M. Kayahan Özgül; edebiyat tarihlerinin, edebiyatları başlangıçlarına ait ilk eserlerden itibaren bütüncül bir bakışla ele almaları gerektiğini ileri sürer. Aynı çalışmada Özgül, Tanpınar'ın On Dokuzuncu Asır Türk Edebiyatı Tarihi'nin aslında 1860-1885 yılları arasında geçen 25 yıldan ibaret olduğuna vurgu yapar ve bu kitap için “edebiyat tarihi”" etiketini o kadar kolay yapıştıramayız der. ${ }^{29}$

\section{1949 Yılındaki Baskısından 1956 Yılındaki Baskısına Metnin Üslûbundaki Değişim}

Her iki baskı arasındaki organizasyon ve içerik değişimi 1946 yılından 1956 yılına kadar geçen sürede Ahmet Hamdi Tanpınar'ın daha akademik bir yaklaşımı, bir edebiyat tarihçisi tavrını benimsediği düşüncesini doğurmaktadır. Bunun yanı sıra, kimi cümlelerin de daha nesnel açıdan yeniden düzenlenmesi bu yargıyı destekler görünür:

Abdülhamid'in Mithat Paşayı memleket dışına çıkarması ile biten bu mücadele esnasında, Ziya Beyle Namık Kemal'in Askere Hediye cemiyet i şeklinde başlıyan ve sonunda, Asakiri Milli taburları teşkili gibi, Fransız ihtilalini lüzumsuz yere -çünki Padişah sözle olsun islahata taraftardır; ve memleket sulh hâlin dedir.- taklid ile biten bir teşebbüsleri vardır $\boldsymbol{k i}$ Abdülhamid' in darbei hükumetini çabuklaştırdığ 1 iddia olunabilir. ${ }^{30}$

1956 yılına ait baskıda aynı kısım şu şekilde dile getirilmiştir:

Abdülhamid'in Midhat Paşa'yı memleket dışına çıkarması ile biten bu mücadele esnasında, Ziya Bey'le Namık Kemal'in Askere Hediye Cemiyeti şeklinde başlayan ve sonunda, Asâkir-i Milliye Taburları adıyla gönüllü askerlerinin teşkili gibi, hiç olmazsa adı dolayısıyla Fransız İhtilali'ni taklit zannını veren bir teșebbüsleri vardır ki, Abdülhamid'in darbe-i hükûmetini çabuklaştırdığg iddia olunabilir. ${ }^{31}$

Her iki kısım karşılaştırıldığında yazarın 1956 yılına ait baskıda yaptığı tespitlerde daha temkinli davrandığı ileri sürülebilir. Ziya Paşa hakkında Mabeyn'de yazılan tezkereleri ele aldığı paragrafta Ahmet Hamdi Tanpınar, On Dokuzuncu Asır Türk Edebiyatı Tarihi'nin 1949 yılındaki ilk baskısında olan "Acaba Abdülhamid oyununu zannımızdan daha açık mı oynuyordu?" cümlesini çıkarır. Tanpınar'ın 1949 yılındaki baskıda yer alan kimi şahsi yorumlarını 1956 yılına ait baskıda çıkararak bazı bölümleri daha nesnel hâle getirmeye çalıştığı söylenebilir: "Netekim yine aynı tezkerede ' Sadrazam hazretlerinin şu gaileli zamanımızı müelliften hali olarak idare-i umûr etmeleri dahi bu türlü adamların buradan tebaüdlerile hasıl olacaktı' cümlesi bunu açıkça gösterir. Acaba Abdülhamid oyununu zannımızdan daha açık mı

29 M. Kayahan Özgül, "Edebiyat Tarihine Manifestik Bir Bakış," Turkish Studies - International Periodical For The Languages, Literature and History of Turkish or Turkic: 8/9, (Summer 2013), 2689.

30 Tanpinar, On Dokuzuncu Asır (1949), 220.

31 Tanpınar, On Dokuzuncu Asır (2016), 308. 
oynuyordu?" 321956 yılına ait baskıda bu ifade şu şekli almıştır: "Nitekim yine aynı tezkerede 'Sadrazam hazretlerinin şu gaileli zamanımızı mevânîden hâlî olarak idâre-i umûr etmeleri dahi bu türlü adamların buradan tebâüdleriyle hâsıl olacaktır' cümlesi bunu açıkça gösterir."33

Bunun yanında Tanpınar, edebiyat tarihinin 1956 yılına ait baskısında 1949 yılındaki baskıda kullandığg kimi iddialı sözcükleri değiştirir. Buna yazarın, 1949 yılından sonra okumalarının artması ve yeni bilgiler edinmesi ile bazı konulara daha çekimser yaklaşması neden olmuştur denebilir. Bu değişikliklerden bazıları şunlardır: "muazzam ve şümullü bir program..."34 / "az çok şümullü bir program"35 "Fakat ricale itimat edemiyor, bir takım mesuliyetsiz, hiçbir siyasî terbiye ve tecrübesi olmıyan adamlarla istişare ediyordu. ${ }^{36}$ / "Fakat ricale ve bilhassa sadrazamlara itimat edemiyor, çoğu mesuliyetsiz, siyasî terbiye ve tecrübeleri az adamlarla istişare ediyordu." "Fr "Fakat zaman geçip de hadiselerin terbiyesiyle yetişen bir nesil iş başına gelince, bir vuzuh peyda olur." 38 / "Fakat zaman geçip de hadiselerin terbiyesiyle yetişen bir nesil iş başına gelince, az çok muayyen hedefler belirmiştir." ${ }^{39}$ Verilen bu örnekler her ne kadar Tanpınar'ın görece daha akademik bir üslûp benimsediğini, 1949 yılından 1956 yılına kadar geçen sürede bir edebiyat tarihçisi tavrı geliştirdiğini düşündürse de metnin tümüne bakıldığında Tanpınar'ın, eleştirilerine yansıyan denemeci üslûbunu koruduğu görülmektedir. Aslında bu üslûp Tanpınar'ın şahsına ait romanlarına, şiirlerine, deneme ve edebiyat tarihine yayılmış bir söyleyiş biçimidir. Orhan Okay, Tanpınar'1 "hikâye ve romancılığında da şairlik tarafı ağır basan bir sanatkâr" olarak niteler ve bu tespitine şairin "bütün nesir sanatını katarak, tarihçiliği ve edebiyat tarihçiliğgi"ni de katar. ${ }^{40}$ Tanpınar'ın kendine has sesi On Dokuzuncu Asır Türk Edebiyatı Tarihi'nde de duyulur. Ziya Paşa'nın incelendiği bölümden alınan ve 1949 yılındaki baskıda ve 1956 yılındaki baskıda ortak olan aşağıdaki paragrafta, 1956 yılındaki baskısında eklenmiş (burada koyu ve italik olarak belirginleştirilen) cümle, bu durumu göstermek için iyi bir örnektir:

İşte zeki ve girgin bir saray adamı, hürriyet âşığı, sırasına göre rind ve kalender, fakat daima muhteris ve zengin hayata düşkün, yaradılıştan büyük devlet adamı edalı, erişmek için çırpınan fakat ikbalin eteğini tutmakta beceriksiz, gizli meramlı, fakat açık sözlü, sabırsız, zalim, kindar fakat aynı zamanda vefalı ve insanları daima affa hazır, hulâsa mizacı ile ihtirasları ve fikirleri arasında perişan Ziya Paşa'nın velveleli ömrü, böylece merkezden ve peşinde koştuğu ikbalden, o kadar sevdiği mücadele ve didişmelerden uzak, yarı göz hapsinde, âdeta ümitlerinin enkazı üstünde, rüşvet yiyen bir mühürdarla, kendisine ve fikirlerine âşı genç

32 Tanpınar, On Dokuzuncu Asır (1949), 221.

33 Tanpinar, On Dokuzuncu Asır (2016), 308.

34 Tanpınar, On Dokuzuncu Asır (1949), 19.

35 Tanpınar, On Dokuzuncu Asir (2016), 70.

36 Tanpinar, On Dokuzuncu Asır (1949), 29.

37 Tanpinar, On Dokuzuncu Asir (2016), 79.

38 Tanpınar, On Dokuzuncu Asır (1949), 35.

39 Tanpınar, On Dokuzuncu Asır (2016), 85.

40 Orhan Okay, “Ahmet Hamdi Tanpınar”, Dergâh Türk Dili ve Edebiyatı Ansiklopedisi, İstanbul: Dergâh Yayınları, (1998), 231. 
bir tahrirat müdürünün, gerek kendisi, gerek Namık Kemal hakkında hatıralarından birçok şeyler öğrendiğimiz Nâzım Bey-ki, paşa olur-arasında, bütün geçmiş felaketlerine verem döşeğinde kahkahalarla gülerek sona erer. Talih, bu zeki, fakat sabırsız ve cömert ruhlu ikbalperestin hayatını zalim bir roman yapmak için hiçbir şeyi esirgememiştir. Kaç defa ikbalin peşinden en yüksek basamaklara kadar yükselmiş, fakat saçlarından yakalayacağı sırada, sadece alaycı kahkahasını duymuştur. ${ }^{41}$

1956 yılına ait baskısında eklenen ve yine şair ve romancı Tanpınar'ın dil ve üslubunu yansıtan bu cümleler de yazarın bilimsel bir çalışmadan beklenen akademik mesafeyi korumakta zorlandığını düşündürür. Zira Tanpınar edebiyat tarihinin pek çok yerinde öne sürdüğü tespitleri doğrulayacak örnekler vermemiş, ileri sürülen görüşler şahsi tespitler olarak kalmıştır. "Düşünür Bir Şairin Edebiyat Tarihi” başlıklı yazısında Hilmi Ziya Ülken On Dokuzuncu Asır Türk Edebiyatı Tarihi'nde Tanpınar'ın özellikle şiirden bahsederken araya kendi felsefi görüşlerini kattığına dikkat çeker. "Sahnede iki ayrı adam görüyorsunuz. Biri geçen asırda yaşamış bir şair veya romancı, öteki Tanpınar'ın kendisi...” diyen Ülken Tanpınar'ın bu metni yazarken kendi kendisiyle diyalog hâlinde olduğunu belirtir. ${ }^{42}$

Bununla birlikte Ahmet Hamdi Tanpınar, şiir eleştirilerinde diğer sanat dalları hakkında sahip olduğu bilgi birikiminden de yararlanmıştır. Bu ışık ve renk tasvirindeki "Yarım ay büyüklüğünde inciler delinmiş, içinde nice bin mürg-i bukalemun-renk âşiyan tutmuştu" imajı ve onun devamı hatta bütün sayfa bize yine resmi, hatta Bosche'un bazı resimlerini hatırlatır. Hulâsa üslûbu bahsinde tekrar döneceğimiz bu küçük eser onun, şiir ve nesir, hayal dünyasının tam değiştiği noktadır. ${ }^{43}$ “Aşsk-1 Memnu'nun Beşir'i, bu romanın Boğaziçi feerisinde* tıpk1 bazı Rönesans tablolarındaki egzotik çehreler gibi görünür." "44 "Bu ahlaki karşıllaştırmaya biraz göz yumun. Dilaşub'da -bütün çehre ayrılıklarına rağmen- Mehpeyker'in devamından başka bir şey görmezsiniz. Bu hemen hemen Titien'in gençlik tablosundaki ilahî aşkla maddi aşk antitezi gibi bir şeydir. İşte bu hâl bizi romanın başlangıcına götürür." 45 "Turhan'da âdeta Wagnerimsi bir tasavvurla her şahsın ayrı bir vezinle konuşması, yine aynı eserde sahne tertibatına ait bazı teferruatın veya esaslı unsurların sinemayla gösterilmesini teklif etmesi, Abdullahü’s-sagîr'de Ferdinando'nun atı ile konuşması bu cinstendir."'46

Yukarıya alınan bütün örneklerde Tanpınar karşımıza şair ve denemeci bir yazar olarak çıkar. Yazarın yaptığı benzetmeler ve malzemesini açıklamak için başvurduğu diğer sanat dalları onun entelektüel birikimini yansıttığı gibi edebiyat eleştirisinde sanatsal söylemin içerisinde kaldığını da gösterir. Daha da çoğaltılabilecek bu örneklerle, bir akademik yayından ziyade "deneme" türünde daha fazla karşılaşılır. Buradan hareketle Tanpınar'ın resim, müzik, mimari ve diğer plastik sanatlara öykünen, onlara sık sık gönderme yapan özgün üslubunun On Dokuzuncu Asır

41 Tanpinar, On Dokuzuncu Asır (2016), 309.

42 Tanpınar, On Dokuzuncu Asır (2016), 637.

43 Tanpınar, On Dokuzuncu Asır (2016), 368.

44 Tanpınar, On Dokuzuncu Asır (2016), 292.

45 Tanpınar, On Dokuzuncu Asır (2016), 398.

46 Tanpınar, On Dokuzuncu Asır (2016), 574. 
Türk Edebiyatı Tarihi'nde de karşımıza çıktığı ileri sürülebilir. Emrah Pelvanoğlu'nun “Ahmet Hamdi Tanpınar'ın Şiir Eleştirisinde Avrupa Merkezlilik” isimli yayımlanmamış yüksek lisans tezinde vurguladığı gibi Tanpınar'daki anlamıyla “tefsir”, onun bu özgün üslubunu anlamada yardımcı olabilir. Pelvanoğlu'na göre Ahmet Hamdi Tanpınar, şiiri, resim, heykel, müzik ve mimarinin de dâhil olduğu güzel sanatlar sisteminin içinde değerlendirmektedir. Tanpınar'ın öznel yorumlara dayanan şiir eleştirisinin de bu özgün güzel sanatlar anlayışına dayandığına dikkat çeken Pelvanoğlu yazarın resim ve plastik sanatlara olan özel ilgisinin şiir eleştirisinin önemli bir parçası olduğunu belirtir. ${ }^{47}$

“Şiir ve Rüya II” başlıklı denemesinin bir bölümünde Tanpınar sanatlara yaklaşımını şöyle açıklar: "Herkes sevdiği bir keman konçertosuna kendi ömrünün bir anısını verebilir, Mozart'1, bir Watteau veya Fêtes Galantes havasında tatmak çaresini bulabilir. Musikinin bu tarzda tefsiri ve görünürler dünyasına tercümesi hepimizin sık sık yaptığımız bir şeydir." ${ }^{48} \mathrm{Bu}$ ifadeyle yazar, dış dünyanın tefsirindeki öznelliğini ve özellikle müzikten örnek vermesiyle, tefsirde sanatların iç içeliğini gösterir. Tanpınar'ın eleştirilerinde, romanlarında, denemelerinde ve şiirlerinde sanatları birbirine bağlayan öznel 'tefsir' üslubu her zaman karşımıza çıkar. Nurdan Gürbilek'in söylediği gibi 'güneş yalnız Huzur'da değil, denemelerinde de nedense hep Turner'ın tablolarında olduğu gibi doğa[caktır]." ${ }^{49}$ Hikmet Dizdaroğlu'nun "Edebiyat Tarihçisi Ahmet Hamdi Tanpınar" başlıklı yazısında belirttiği gibi "bir çağın genel tablosunu çizer, ya da bir sanatçıyı değer ölçüsüne vururken, tam bir ressam gibi davran[acaktır]. ${ }^{{ }^{50} \mathrm{Bu}}$ yüzden belki de eleştirilerinde denemeci ya da şair Tanpınar'ın görüldüğü yorumundan kaçarak hepsinde ortak bir üslubun, bir 'tefsir' tavrının olduğunu söylemek daha doğrudur.

Orhan Okay’ın ifadesiyle Tanpınar, On Dokuzuncu Asır Türk Edebiyatı Tarihi adlı çalışmasında "batılılaşma dönemini kendine mahsus sanatkârane yorumlarıyla aktarır." Buradan hareketle Tanpınar'ın edebiyat tarihçisi olarak yeni bir söylem inşa etmediği, kurmaca metinlerine ve şiirlerine hâkim olan söyleyiş tarzıyla on dokuzuncu asrın edebiyatına yaklaştığ 1 ileri sürülebilir. Bu durum “On Dokuzuncu Asır Türk Edebiyatı Tarihi’ni bir edebiyat tarihi olarak ele almak mümkün müdür?” sorusunu akla getirir. Zira bu metin Türk Edebiyatı tarihi içerisinde yayımlanan diğer edebiyat tarihlerinden yazarın kurmacaya ve şiire benzeyen üslûbu dolayısıyla farklılık taşır. Emrah Pelvanoğlu'nun 2014 yılında düzenlenen Türk Edebiyatı Tarihi Yazımı Çalıştayı' daki bildirisinde dikkat çektiği gibi Ahmet Hamdi Tanpınar her şeyden önce bir şair ve yazardır. Doyısıyla onun ürettikleri romanla dünyayı yeniden kuran bir zihnin

47 Emrah Pelvanoğlu, “Ahmet Hamdi Tanpınar’ın Şiir Eleştirisinde Avrupa Merkezlilik”, Ankara: Bilkent Üniversitesi, (2006), (Yayımlanmamış Yüksek Lisans Tezi).

48 Ahmet Hamdi Tanpınar, "Şiir ve Rüyâ II", Edebiyat Üzerine Makaleler, haz. Zeynep Kerman (İstanbul: Dergâh Yayınlar1 2000), 38.

49 Nurdan Gürbilek “Kurumuş Pınar, Kör Ayna, Kayıp Şark”, Kör Ayna Kayıp Şark (İstanbul: Metis Yayınları 2004), 72 .

50 Hikmet Dizdaroğlu, "Edebiyat Tarihçisi Ahmet Hamdi Tanpınar”, Bir Gül Bu Karanlıklarda: Tanpınar Üzerine Yazılar, haz. Abdullah Uçman ve Handan İnci, İstanbul: Kitabevi, 2002.

51 Neslihan Demirci, “Orhan Okay'la Türk Edebiyatı Tarihi Üzerine”, Türkiye Araştırmaları Literatür Dergisi: Yeni Türk Edebiyatı Tarihi: I, 4, No. 7 (2006): 351-359. 
eseridir. Tanpınar karşılaştığı metinleri bu zihin dünyasında dönüşüme uğratarak sunmuş, nesnesine karşı mesafeyi birtakım ironik oyunlar yoluyla kurmuştur. ${ }^{52}$ Metinlere yaklaşımındaki bu tavır onu diğer edebiyat tarihi yazarlarından ayırır. Tanpınar'ın edebiyat tarihinde metnin eleştirel süreçlerden geçirilerek incelenmesinden daha çok metinlerin bir romancı gözünden dönüşüme uğratılarak sunulması vardır.

\section{Sonuç}

Bu çalışmada Ahmet Hamdi Tanpınar'ın On Dokuzuncu Asır Türk Edebiyatı Tarihi'nin 1949 yılında yayımlanan ilk baskısı ile 1956 yılında yayımlanan, gözden geçirilmiş ve genişletilmiş ikinci baskısı karşılaştırılmıştır. İki baskı arasındaki farklar metin içi organizasyon, içerik ve yazarın üslubu çerçevesinde değerlendirilmiştir. Yapılan bazı değişiklikler anlamlı bir nedene bağlanabilirken bazı değişiklerin sadece yazarın ikinci baskıyı hazırlarken yaptığı kişisel tercihlere dayandığ 1 görülmüştür.

“1949 Yılındaki Baskısından 1956 Yılındaki Baskısına Metnin Organizasyonundaki Değişim” başlığını taşıyan ilk bölümde, iki baskı arasındaki başlıklandırma ve kaynak gösterme farklılıkları üzerinde durulmuş, 1949 yılındaki baskıda On Dokuzuncu Asır Türk Edebiyatı Tarihi' nin daha serbest bir şekilde organize edildiği görülmüştür. "1949 Y1lındaki Baskısından 1956 Yılındaki Baskısına Metnin İçeriğindeki Değişim” başlığını taşıyan ikinci bölümde ise iki baskı arasındaki içerik farklılıkları ele alınmıştır. "1949 Yılındaki Baskısından 1956 Yılındaki Baskısına Metnin Üslûbundaki Değişim” başlığını taşıyan son bölümde ise iki baskı arasındaki üslûp farklarına odaklanılmıştır. Gerek organizasyonun daha akademik bir biçime bürünmesi gerekse eklenen kısımların daha kapsamlı ve yetkin bir çalışmayı ortaya çıkarması Tanpınar'ın bir önceki baskıya nazaran edebiyat tarihçisi tavrını benimsediğini ve daha akademik bir üslûpla yazdığını düşündürmektedir. Ancak metin bütünüyle incelendiğinde 1956 baskısında da üslubun Tanpınar'ın romanlarında, denemelerinde ve şiirlerinde rastladığımız öznel 'tefsir' üslubu olduğu görülmüştür.

1949 yılına ait baskı ile 1956 yılına ait baskı arasındaki farklar karşılaştırıldığında yazar tarafından yapılan değişikliklerin sistemli bir gözden geçirme ve düzeltme sonucu gerçekleştiğini söylemek zordur. Bu değişikliklerin bir bölümünde Tanpınar'ın metnine daha bilimsel yaklaşmaya çalıştığı görülürken kimi yerlerde yazarın nesnel verilere dayanmayan şahsi yorumlarına da yer verdiği görülmektedir. Bunun yanında 1956 yılındaki baskıya eklenen dipnotlar, açıklamalar ve tarihlerdeki düzeltmeler ile eklenen yeni bilgiler göz önüne alındığında Tanpınar'ın 1956 yılındaki baskıyı hazırlarken tarihçiliğin nesnellik idealine daha yakın durduğu söylenebilir. Ancak Ahmet Hamdi Tanpınar, edebiyat tarihçisinden önce bir romancıdır ve dış dünyayı romancı gözüyle algılar. Bu durum onun edebiyat metinlerine yaklaşımını da etkilemiştir. On Dokuzuncu Asır Türk Edebiyatı Tarihi okuyucuya on dokuzuncu asırda edebiyat dünyasında

52 Emrah Pelvanoğlu, "Tarih-Tasnif ve Tahlil Arasında Ahmet Hamdi Tanpınar (1901-1962)- Mehmet Kaplan (1915-1986)", Türk Edebiyatı Tarihi Yazımı Çalıştayı'nda Sunulan Bildiri (26 Aralık 2014), Atatürk Kültür, Dil ve Tarih Kurumu, Atatürk Kültür Merkezi, Ankara, https://www.youtube.com/watch?v=2_qdrGx_26E 
ne olup bittiğinden çok, olup bitenleri Tanpınar'ın nasıl gördüğünün bilgisini verir. Bu metin Tanpınar'ın şiiri, romanı ve denemeciliği ve edebiyat tarihçiliği arasında salınımlı bir sarkaç gibidir. Dolayısıyla edebiyat tarihçiliğinden beklenen bilimselliği ve nesnelliği karşılamada görece yetersizdir. Ahmet Hamdi Tanpınar'ın edebiyat metinlerine yaklaşımı ve üslûbu bu metnin on dokuncu asır Türk edebiyatı hakkında bilgi veren ikincil kaynak olarak değerlendirilmesini de sorunlu kılar. Bunun yanında M. Kayahan Özgül'ün de değindiği gibi metin bütüncül bir Türk edebiyatı tarihi sunmaktan uzaktır, sadece belirli bir döneme odaklanmıştır.

Bütün bunlardan hareketle On Dokuzuncu Asır Türk Edebiyatı Tarihi’ni Türk Edebiyatı üzerine yazılmış diğer edebiyat tarihleriyle kullanılan yöntem, içerik ve üslûp bakımlarından karşılaştırmalı olarak incelemek, bu metnin edebiyat tarihi olarak değerlendirilip değerlendirilemeyeceği sorusuna da cevap olacaktır.

Teşekkür/Acknowledgement: Çalışmanın konusu ile yöntemini belirleme ve makale yazım sürecindeki yönlendirmeleri için Öğr.Üyesi Dr. Emrah Pelvanoğlu'na teşekkürü borç biliriz.

Hakem Değerlendirmesi: Dış bağımsız.

Çıkar Çatışması: Yazarlar çıkar çatışması bildirmemiştir.

Finansal Destek: Yazarlar bu çalışma için finansal destek almadığını beyan etmiştir.

Peer-review: Externally peer-reviewed.

Conflict of Interest: The authors have no conflict of interest to declare.

Grant Support: The authors declared that this study has received no financial support.

\section{Kaynaklar/References}

Akün, Ömer Faruk. “Ahmet Hamdi Tanpınar”. Türk Dili ve Edebiyatı Dergisi XII, Aralık (1962):1-32.

Çelebi, Asaf Halet. “ On Dokuzuncu Asır Türk Edebiyatı Tarihi”. Türk Yurdu Dergisi 259, (Ağustos 1956): 151-154.

Demirci, Neslihan. “Orhan Okay'la Türk Edebiyatı Tarihi Üzerine”. Türkiye Araştırmaları Literatür Dergisi: Yeni Türk Edebiyatı Tarihi: I. 4.no.7 (2006): 351-359.

Dizdaroğlu, Hikmet. "Edebiyat Tarihçisi Ahmet Hamdi Tanpınar". Bir Gül Bu Karanlıklarda: Tanpınar üzerine yazılar. Haz. Abdullah Uçman ve Handan İnci. İstanbul: Kitabevi, 2002.

Eralp, H. Vehbi. “Ahmet Hamdi Tanpınar'ın On Dokuzuncu Asır Türk Edebiyatı Tarihi”. Yeni Sabah, 22 Haziran (1942): 2.

Gürbilek, Nurdan. “Kurumuş Pınar, Kör Ayna, Kayıp Şark”. Kör Ayna, Kayıp Şark. İstanbul: Metis Yayınları, 2004.

Kaplan, Mehmet. “On Dokuzuncu Asır Türk Edebiyatı Tarihi”. Şadırvan: Haftalık Sanat Mecmuası 1: 9, 27 Mayis (1949): 7.

Okay, Orhan. "Ahmet Hamdi Tanpınar". Dergâh Türk Dili ve Edebiyatı Ansiklopedisi. İstanbul: Dergâh Yayınlar1, (1998).

- "Şiirler, Romanlar ve Akademik Yorgunluklar Arasında On Dokuzuncu Asır Türk Edebiyatı Tarihi”. Toplumbilim. Ahmet Hamdi Tanpinar Özel Sayısl 20 (2006): 13-20. 
Özgül, M. Kayahan. "Edebiyat Tarihine Manifestik Bir Bakış”. Turkish Studies - International

Periodical For The Languages, Literature and History of Turkish or Turkic: 8/9.(Summer 2013), 2685-2700.

Pelvanoğlu, Emrah. “Ahmet Hamdi Tanpınar'ın Şiir Eleştirisinde Avrupa Merkezlilik”. Yayımlanmamış Yüksek Lisans Tezi, Ankara: Bilkent Üniversitesi (2006).

Pelvanoğlu, Emrah. "Tarih-Tasnif ve Tahlil Arasında Ahmet Hamdi Tanpınar (1901-1962)- Mehmet

Kaplan (1915-1986)". Türk Edebiyatı Tarihi Yazımı Çalıştayı'nda Sunulan Bildiri (26 Aralık 2014). Atatürk Kültür, Dil ve Tarih Kurumu, Atatürk Kültür Merkezi. Ankara, https://www.youtube.com/watch?v=2 qdrGx_26E.

Rado, Şevket. “Edebiyatımızda Bir Tenkit Hadisesi”, Akşam. Nisan (1949): 2.

Tanpınar, Ahmet Hamdi. On Dokuzuncu Asır Türk Edebiyatı Tarihi. İstanbul: Üçler Basımevi (1949).

- On Dokuzuncu Asır Türk Edebiyatı Tarihi. İstanbul: Dergâh Yayınları, 2016.

- “Şiir ve Rüya II”. Edebiyat Üzerine Makaleler. Haz. Zeynep Kerman, İstanbul: Dergâh Yayınları (1998): 36-39.

Ülken, Hilmi Ziya. "Düşünür Bir Şairin Edebiyat Tarihi”. haz. Abdullah Uçman. On Dokuzuncu Asır Türk Edebiyatı Tarihi. İstanbul: Dergâh Yayınları, (2016): 636-640.

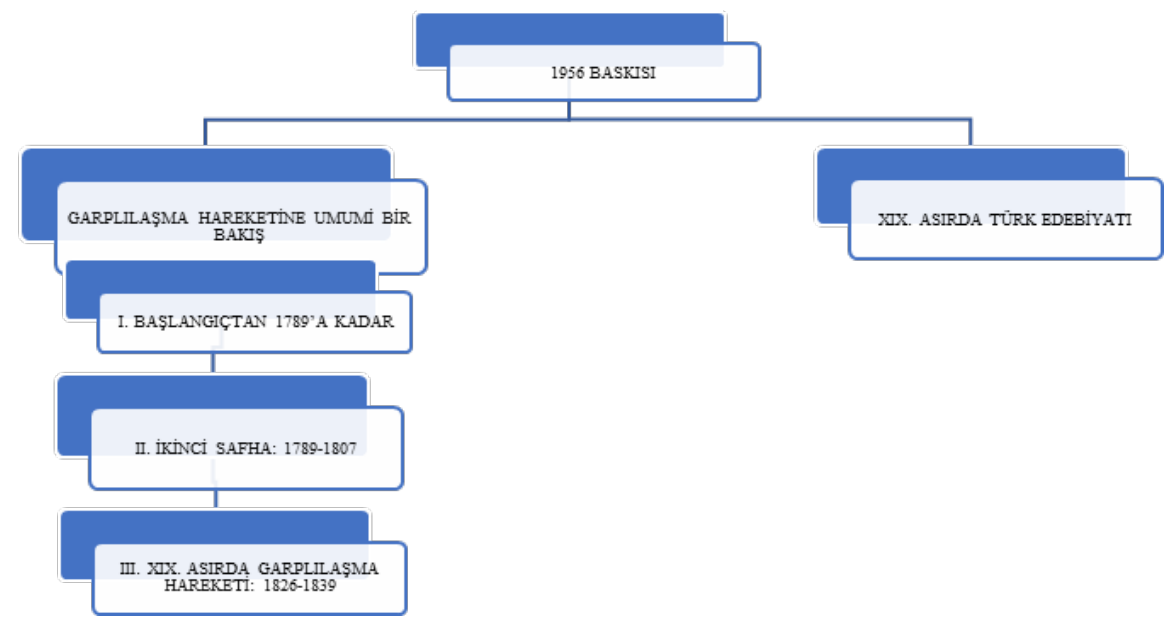

Tablo 1: On Dokuzuncu Asır Türk Edebiyatı Tarihi’nin 1956 Bs. Başlık Organizasyonu Şeması. 
XIX. Asırda Türk Edebiyatı

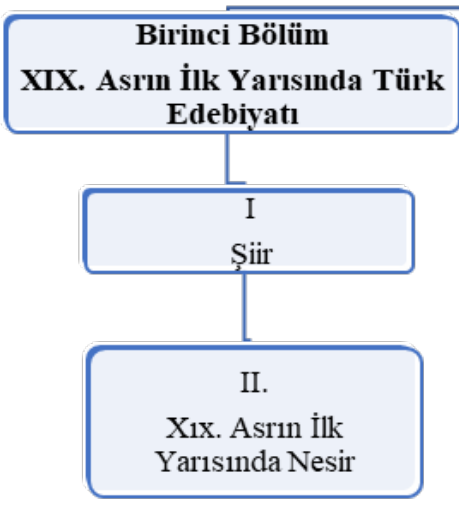

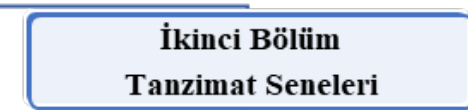

Tanzimat Seneleri

\begin{tabular}{|c|}
\hline I 1839'dan 1860'a Kadar \\
\hline I1 1856-1876yilları \\
\hline Yeniliğin Üç Büyük Muharriri \\
\hline $\begin{array}{c}\text { Şinasi'den Sonra Yeni Osmanlılar } \\
\text { Cemiyeti }\end{array}$ \\
\hline Şinasi'den Sonra Nevilerin \\
Gelișmesi
\end{tabular}

Şinasi'nin Yanıbaşında Ziya Paşa

Şinasi'den Sonra Namık Kemal

Namık Kemal'in Yanı Başında Ahmed Midhat Efendi

Namik Kemal'den Sonra Recaizâde

Mahmud Ekrem Bev

Namık Kemal'den Sonra Abdülhak Hâmid

Eski İle Yeninin Arasında Muallim Naci Efendi

Tablo 2: On Dokuzuncu Asır Türk Edebiyatı Tarihi'nin 1956 Bs. Alt Başlık Organizasyonu Şeması.

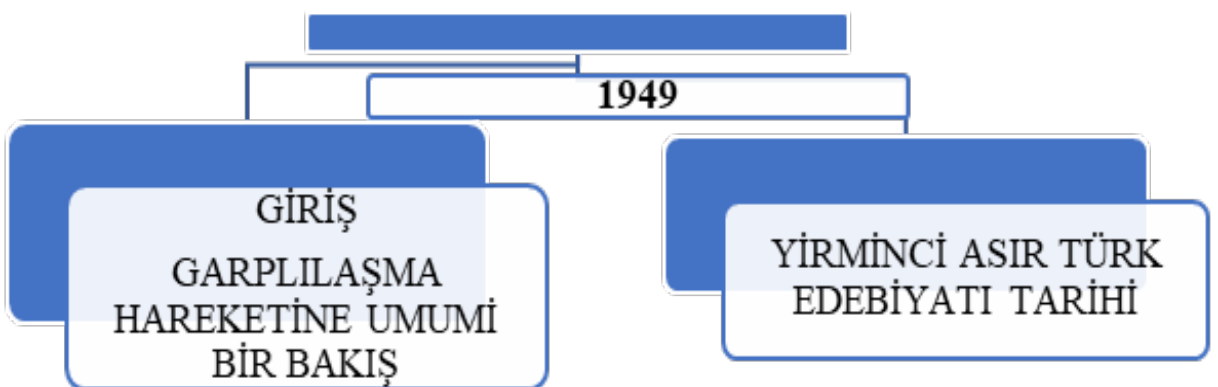

Tablo 3: On Dokuzuncu Asır Türk Edebiyatı Tarihi’nin 1949 Bs. Başlık Organizasyonu Şeması. 


\section{YİRMIINCİ ASIR TÜRK EDEBIYYATI}

TARIHI

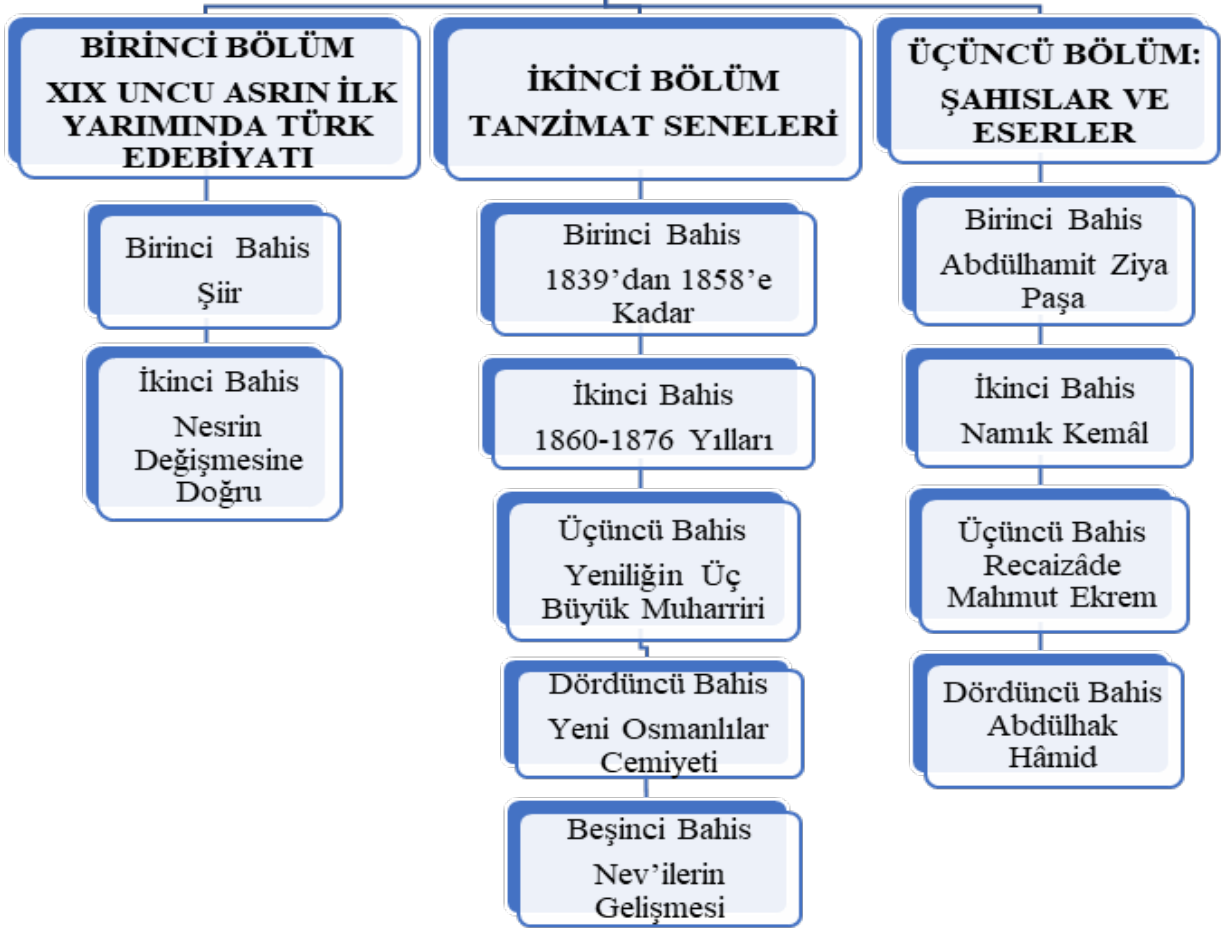

Tablo 4: On Dokuzuncu Asır Türk Edebiyatı Tarihi'nin 1949 Bs. Alt Başlık Organizasyonu Şemas1 
